\title{
Cikkismertetés: Gyökeres fordulatra van szükség a globális egészség terén?
}

\author{
Article review: Global health: time for radical change?
}

Ismertető: $\quad$ Vitrai József $₫$

Ismertetett cikk: Editorial: Global health: time for radical change? The Lancet, 2020;396(10258):1129. DOI:10.1016/S0140-6736(20)32131-0

Beküldve: $\quad$ 2020.10.18.

doi: $\quad$ 10.24365/ef.v61i4.645

Kulcsszavak: globális egészség; GBD; demográfia; migráció

Keywords: global health; GBD; demographics; migration

Milyen stratégiákat kell elfogadniuk a kormányoknak polgáraik egészségének javítása érdekében? A COVID-19 járvány közepette könnyű lenne a globális egészségügyi biztonságra összpontosítani legalább az erős népegészségügyi és egészségügyi rendszerekre. A WHO globális egészségügyi stratégiáját három pillérre alapozta: 1) a mindenkinek járó egészségbiztosításra; 2) az egészségügyi vészhelyzetekre; valamint 3) a jobb egészségre és jóllétre. A szilárd népegészségügy és az egészségügy nélkülözhetetlen elemei jól ismertek és számtalanszor megerősítették azokat: megfelelő egészségügyi munkaerő; hatékony, biztonságos, és magas színvonalú szolgáltatásnyújtás; egészséginformációs rendszerek; az alapvető gyógyszerekhez való hozzáférés; elegendő finanszírozás; és a jó irányítás. De vajon a globális egészségügy fókusza nem túl szűk? Az egészségügyi vezetők és az érintettek képviselői megfeledkeztek-e az emberi egészség legfontosabb meghatározóiról?

A „Betegségek, sérülések és kockázati tényezők globális terhe (GBD) 2019" címú jelentés kellemetlen kérdéseket vet fel a globális egészség 21. századi tendenciáival kapcsolatban. Egyrészt, a hírek jónak tűnnek. A világ népességének egészsége folyamatosan javul. A születéskor várható élettartam globálisan a 2000-es 67,2 évről 2019-re 73,5 évre nőtt. A várható egészséges élettartam 204 országból 202-ben nőtt. A születéskor várható egészséges élettartam 21 országban több mint 10 évvel nőtt 1990 és 2019 között. Az 5 év alatti gyermekek halálozásainak becsült száma a 2000-es 9,6 millióról 2019-re 5 millióra csökkent. Az 100 ezer főre számított elvesztett egészséges életév (DALY) arányának csökkenése 1990 óta a fertőző, az anyai, újszülöttkori és táplálkozási betegségek esetében a legnagyobb - és a fejlődés az elmúlt évtizedben a leggyorsabb volt.

De a GBD jelentésből az is kiderül, ismételten, hogy az egészség nemcsak az egészségügyi rendszertől függ. Az egészség és a társadalmi-demográfiai index - azaz egy ország általános fejlődésének összefoglaló mutatója, melyet az egy főre jutó átlagjövedelem, az iskolai végzettség és a teljes termékenységi arány alapján számítanak ki - közötti erős korreláció azt sugallja, hogy az egészségügyi ágazatnak meg kell fontolnia az aggodalomra okot adó tényezők körének újradefiniálását. 
A GBD-2019 a demográfiai átmenet felülvizsgált elméletét is kínálja, amely hét különböző szakaszt azonosít. Figyelemre méltó újítás a „késői átmenet” és az „átmenet utáni” szakaszok bevezetése, amelyeket a migrációs státuszra bontva alakítanak ki. 35 ország, nagyrészt a Fekete Afrikában és a KözelKeleten, az „átmenet-közbeni” szakaszban van, csökkenő születési és halálozási rátával (2019-ben egyetlen ország sem volt az "átmenet előtti” szakaszban). Az olyan országok, mint Brazília, Kína és az USA a "késői átmeneti” szakaszban vannak, a halálozási arány stagnál, míg a születési ráta továbbra is csökken. Végül az „átmenet utáni” szakasz az, amikor a születési arány alacsonyabb, mint a halálozási arány, és a természetes népesség növekedése negatív, vagyis csökken - ahogy Japánban, Olaszországban és Oroszországban is megfigyelhető. E demográfiai szakaszokra gyakorolt fontos és figyelmen kívül hagyott hatás a migráció: 17 ország, köztük Spanyolország, Görögország és számos kelet-európai ország az "átmenet utáni” szakaszban, nettó kivándorlással "bizonytalan állapotban" van. Itt olyan szakpolitikákra van szükség, amelyek csökkentik az egyre inkább fordított népességi piramis társadalmi és gazdasági hatásait - és erre a bevándorlás ösztönzése lehet a megoldás.

Ezen érvek egyike sem arra utal, hogy a mindenki számára elérhető egészségbiztosítás és a globális egészségügyi biztonság irreleváns lenne az egészségre. Ahogy a 2019-es GBD szerzői állítják, egyes országokban hosszabb a várható élettartam, mint azt a fejlődési szakaszuk előre jelezné. Ezek a túlteljesítő nemzetek - például Niger, Etiópia, Portugália és Spanyolország - valószínúleg kiváló népegészségügyi és egészségügyi politikákkal rendelkeznek. A GBD 2019 azt sugallja, hogy a globális egészségügyi közösségnek radikálisan újra kell gondolnia jövőképét. Hiba az egészségügyre való kizárólagos összpontosítás. Az egészség több szektor „terméke": a legfontosabb meghatározó tényezők az oktatás (alaptól a felsőfokúig) minősége, a gazdasági növekedés, a nemek közötti egyenlőség és a migrációs politika.

Ez a következtetés közvetlenül érinti a COVID-19 kezelésére irányuló nemzeti stratégiákat. Bár figyelmet kell fordítani a koronavírus közösségi átvitelének ellenőrzésére és a következményeinek leginkább kitett személyek védelmére, a siker ennél tágabb megközelítésre épülő stratégiát igényel. A COVID-19 járvány a koronavírus fertőzés és a nem fertőző betegségek járvány együttese, amelynek következményeit a társadalomban megtalálható szegénység és egyenlőtlenség befolyásolja. A GBD jelentés fontos üzenete: a társadalomba mélyen beágyazott egyenlőtlenségeket csökkenteni kell, liberálisabb bevándorlási politikát kell folytatni ahhoz, hogy a jövőbeli fertőző járványok kitöréseitől a közösségek védve legyenek, és hogy a lakosság egészsége olyan mértékben javuljon, amilyenre a globális egészségügy támogatói törekszenek. Itt az ideje, hogy a globális egészségügyi közösség irányt változtasson.

\section{TANULSÁGOK A HAZAI SZAKEMBEREK SZÁMÁRA}

Alapvetően új megközelítés szükséges hazánkban is az újonnan és a korábban felmerült egészségproblémák leküzdésére. Az egészségügynek az eddiginél sokkal szorosabb együttmúködésben kell cselekednie más szektorokkal a fertőző és a nem fertőző betegségek elterjedésében kulcsszerepet játszó egészségegyenlőtlenségek csökkentése, valamint a demográfiai változások kedvezőtlen hatásainak enyhítése érdekében. 